\title{
Binding ability of lacosamide to phosphatidylcholine lipids with cholesterol effects
}

\section{Lakozamid'in fosfatidilkolin lipitlerine bağlanma kapasitesi ve kolesterolün etkisi}

\author{
Burçin YAĞIŞ $\odot$, Sevgi TÜRKER KAYA ๑
}

\begin{abstract}
Aim: In the present study, in order to obtain information about binding profile of lacosamide (LCM) with membrane lipids, which is the most important parametre that determines its availability in the central nervous system, we aimed to analyze molecular interaction of LCM with model membranes formed by well-known representative lipids of biological membranes .
\end{abstract}

Methods: The effects of varied concentrations (1-10-20 mol \%) of LCM on biophysical parameters of dipalmitoylphosphatidylcholine multilammelar vesicles in the absence and presence of cholesterol (10 mol \%) were studied by differential scanning calorimetry and fourier transform infrared spectroscopy.

Results: According to the data obtained in all concentrations LCM decreased main transition temperature and enthalpy with broaden transition curve. However, LCM at 1 mole \% affected such values mostly in comparison with $10-20$ mol\% concentrations. With the addition of $\mathrm{CHO}$ to $20 \mathrm{~mol} \%$ of LCM sample, these parameters were significantly lowered. Moreover, LCM at high concentrations prominently increased both order of lipid phases, and hydrogen binding capacity of glycerol and phosphate groups of lipids but reduced fluidity. Also, $\mathrm{CHO}$ was found to tend to reverse these effects of LCM except for order and fluidity parameters.

Conclusion: According to the findings obtained, in accordance with its chemical structure, LCM leads to alteration of thermotrophic parameters, structures and functions of phosphatidylcholine lipids abundant in brain cell membrane, which also show the penetration ability of LCM into biological membranes. But, the degree of such behavior can be dependent on applied concentration of LCM and presence of CHO. In summary, all data may provide information for its use in therapeutic strategies of epilepsy and development of new antiepileptics.

Keywords: Lacosamide, dipalmitoylphosphatidylcholine, cholesterol, infrared spectroscopy, differential scanning calorimetry
Öz

Amaç: Bu çalışmada amaç, Lakozamidin (LCM) merkezi sinir sistemindeki etkinliğini belirleyen en önemli parametre olan zar lipidleri ile bağlanma profili hakkında bilgi elde etmek için, biyolojik zarların en iyi bilinen temsili lipidleri tarafından oluşturulmuş model zarlarla LCM'nin moleküler etkileşimi incelemektir.

Yöntem: Bu amaç doğrultusunda, farklı konsantrasyonlarda (1-10-20 mol\%) LCM'nin dipalmitoilfosfatidilkolin çok tabakalı veziküllerin biyofiziksel parametreleri üzerindeki etkileri kolesterolün $(\mathrm{CHO})$ yokluğunda ve varlığında (\% $10 \mathrm{~mol}$ ) diferansiyel tarama kalorimetrisi ve fourier transform infrared spektroskopisi ile araştırıldı.

Bulgular: Elde edilen verilere göre, tüm konsantrasyonlarda LCM'nin ana geçiş sıcaklığını, ana geçiş eğrisinde genişleme ile birlikte entalpiyi azalttığı, bununla birlikte, $\% 1 \mathrm{~mol}$ oranında LCM'nin, \%10-20 mol konsantrasyonlarına kıyasla bu değerleri en fazla etkilediği belirlendi. Öte yandan, CHO'ün \%20 mol'e eklenmesiyle, bu parametrelerde önemli ölçüde azalmaya neden olduğu bulundu. Ayrıca, yüksek konsantrasyondaki LCM, gliserol ve fosfat gruplarının hidrojen bağı yapma kapasitelerini ve lipid düzenini arttırmış fakat akışkanlığı azaltmıştır. Ayrıca, CHO'nun lipit düzeni ve akışkanlık dışında LCM'nin bu etkilerini tersine çevirme eğiliminde olduğu bulundu.

Sonuç: Elde edilen bulgulara göre kimyasal yapısına uygun olarak LCM, beyin membranında bol miktarda bulunan fosfatidilkolin lipitlerinin termotrofik parametrelerinin, yapılarının ve işlevlerinin değişmesine yol açması LCM'nin biyolojik membranlara nüfuz etme yeteneğini göstermektedir. Ancak, bu tür davranışların derecesi, uygulanan LCM konsantrasyonuna ve CHO'nun varlığına bağlı olabilir. Özetle, tüm veriler epilepsinin terapötik stratejilerinde kulıanımı ve yeni antiepileptiklerin geliştirilmesi için bilgi sağlayabilir.

Anahtar kelimeler: Lakozamid, dipalmitoilfosfatidilkolin, kolesterol, kızılötesi spektroskopisi, diferensiyel tarama kalorimetresi

Received: 22.03 .2018

Accepted: 17.07.2018

Kocaeli University, Faculty of Arts and Sciences, Department of Biology, 41380 - Kocaeli - Turkey

Yazışma adresi: Sevgi Türker Kaya, Kocaeli University, Faculty of Arts and Sciences, Department of Biology, 41380 - Kocaeli - Turkey

e-mail: sevgitrkr@gmail.com

Yazarların ORCiD bilgileri: 


\section{INTRODUCTION}

Lacosamide (LCM) ([R]-2-acetamidoN-benzyl-3methoxyproprionamide), (UCB, Inc. Smyrna, GA), (Figure 1) is an antiepileptic drug with a molecular weight of 250.30 Da used as add-on therapy for partial-onset seizures with antinociceptive and neuroprotective activities ${ }^{1,2}$. Also named vimpat, harkoseride and SPM 927, it is an analog of the amino acid L-serine. The primary mechanism by which LCM exerts its anticonvulsive effect is related to its role in the enhancement of slow inactivation of component of voltage-gated sodium channels (VGSCs) without affecting the fast inactivation, thereby stabilizing hyperexcitable neuronal membranes ${ }^{1-6}$. LCM has amphiphilic properties, allowing the molecule to be sufficiently water soluble $(0.465 \mathrm{mg} / \mathrm{ml})$, but also lipophilic enough to cross the blood-brain barrier (logP $-0,02)^{7}$. It has hydrogen- bond donor and acceptor count as 2 and 3 , respectively. Its topological polar surface area is $67.4 \mathrm{~A} 2^{8}$. Based on such characteristics, LCM shows favorable pharmacokinetic profile in humans, with rapid and complete absorption, low plasma protein binding $(<15 \%)$, and low potential for clinically relevant drug-drug interactions ${ }^{9,10}$. In addition, the drug is rapidly absorbed after oral administration, reaching maximum plasma concentrations after $0.5-4 \mathrm{~h}$ and it is almost completely eliminated in the urine within about $13 \mathrm{~h}^{11}$.

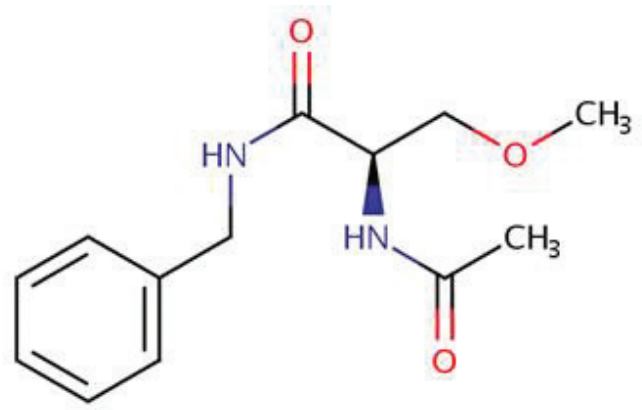

Figure 1. Chemical structure of lacosamide.

Since LCM exerts its action on VGSCs (4-5) that are integral proteins in central nervous system (CNS), it inevitably interacts with membrane lipids in order to reach target sites in CNS, and thereby binding at correct position to VGSCs like other antiepilep- tic agents ${ }^{12,13}$. For that reason, the penetration of LCM into lipids directly affect its pharmacokinetic and pharmacological properties including its CNS availability $^{12-15}$ as well as its toxicity and cell resistancy as shown for different drugs ${ }^{14,15}$. Thus, the evaluation of LCM in terms of the binding ability with membrane lipids may provide additional information for its partition profile, and accordingly its effective use in epilepsy treatment. However, although LCM is expected to interact with membrane lipids due to its high distribution pattern throughout the body and very low protein binding capacity ${ }^{9-11,16}$, there is no published data on LCM-lipid interaction to the best of our knowledge.

Displaying a very high complexity with varied lipid, proteins and carbohydrates, biological membranes are accompanied by some disadvantages to examine drug-lipid interactions because of difficulties in the interpretation of the results. Thus, usage of model membrane systems which offer specific information is a general approach for such studies ${ }^{18,22-24}$. Specifically, the composition of outer leaflet of plasma membranes of mammalian cells consists of phosphatidylcholines (PC) and sphingomyelin, which together reach to abundant amounts in most membranes, and the other main components such as cholesterol (CHO) found up to $50 \mathrm{~mol} \% 23,25$. Model systems made up of $\mathrm{CHO}$ and major lipid components such as PC lipids like dipalmitoylphoshatidiylcholine (DPPC) have been widely used to mimic biological membranes ${ }^{13-15,21,22,24,25}$.

It is very well-known that when drug molecules interact with membrane lipids, biophysical parameters of lipids such as phase transition enthalpy $(\Delta \mathrm{H})$, phase transition temperature ( $\mathrm{Tm})$, lipid order, lipid fluidity and hydrogen state of glycerol and phosphate groups are changed. By monitoring such changes in model membrane systems the information about the degree of interaction and behaviour of the drug in real membrane systems can be obtained ${ }^{14,17,26-27}$. Similarly, in the present study we aimed to provide information for binding ability of LCM with PC membrane lipids, and designed our experiments on a well-established 
molecular models of biomembranes ${ }^{13,18,22,24,26}$, multilamellar vesicles (MLVs) formed by DPPC and $\mathrm{CHO}$ lipids, as similarly performed for phenytoin, ${ }^{12}$ and gabapentin and levetricetam ${ }^{13}$. Indeed, in the absence and the presence of $\mathrm{CHO}(10 \mathrm{~mol} \%)$, the effects of LCM at different concentrations (1-10-20 mol\%) on biophysical parameters of DPPC MLVs were investigated. To achieve this, Fourier transform infrared (FT-IR) spectroscopy and differential scanning calorimetry (DSC) were utilized as in earlier studies ${ }^{12,13,17-19,22,24-27}$.

\section{MATERIAL and METHODS}

\section{Chemicals}

Pure active substance of LCM, DPPC, CHO and phosphate buffered saline (PBS) tablets at the highest available grade of purity were purchased from Sigma (Sigma Chemical Co, St Louis, Mo, USA).

\section{Preparation of MLVs}

MLVs containing pure DPPC, 1-10-20 mol\% LCM+DPPC and $20 \mathrm{~mol} \% \mathrm{LCM}+10 \mathrm{~mol} \% \mathrm{CHO}+\mathrm{DPPC}$ were prepared in accordance with the previous reports ${ }^{13,22,24,28}$. Briefly, $5 \mathrm{mg}$ of DPPC lipid was initially dissolved in chloroform in a round-bottom glass tube, and $5 \mathrm{mg}$ DPPC was accepted as $100 \mathrm{~mol} \%$, which was $6.8 \times 10-6$ mol. Then the solvent was removed under nitrogen flow and dessicated vacuum to obtain thin dried lipid film. The films were re-suspended in PBS buffer, which was already obtained by dissolving PBS tablets in deionized water, resulting in a solution of $0.01 \mathrm{M}$ phosphate buffer with $0.0027 \mathrm{M}$ potassium chloride and $0.137 \mathrm{M}$ sodium chloride with a $\mathrm{pH}$ of 7.4. MLVs were formed by vigorous vortexing the mixture for $30 \mathrm{~min}$ at about $60^{\circ} \mathrm{C}$ that is above the main phase transition temperature (Tm) of DPPC lipids. To prepare $1 \mathrm{~mol} \%$ of LCM containing MLVs, the appropiate amount of LCM $(6.8 \times 10-6 \mathrm{~mol} \times 1 / 100=6,8 \times 10-8$ $\mathrm{mol}=1,70 \times 10-5 \mathrm{~g}$ ) was taken from a stock solution, in which LCM was dissolved in ethanol and placed in a round-bottomed a glass tube. Excess ethanol was evaporated by nitrogen stream and then DPPC in chloroform was added. The solvents were again eva- porated by a stream of nitrogen, and MLVs were prepared as described above. In order to produce other MLVs, the required amounts of DPPC, LCM and $\mathrm{CHO}$ were calculated by using the same proportioning and similar procedures.

\section{FT-IR Studies and Analysis}

Infrared spectrum of each MLVs was acquired by a Perkin Elmer Spectrum 100 FT-IR spectrometer (Perkin Elmer, Inc., Norwalk, CT, USA) equipped with a deuterated triglycine sulfate detector. The sample was placed between calcium fluoride windows with $12 \mu \mathrm{m}$ spacer to give sample thickness. The interferograms were averaged for 200 scans at $2 \mathrm{~cm}^{-1}$ resolution. Each sample were scanned between $25-60^{\circ} \mathrm{C}$ temperature range with increasing rate of $3^{\circ} \mathrm{C}$, and at each temperature degree the samples were incubated for $5 \mathrm{~min}$. All experiments were performed three times. The sample compartment in the FT-IR spectrometer was continuously purged with dry air to prevent water vapor. The spectrum of air was automatically subtracted by Perkin Elmer Spectrum One software (Perkin Elmer, Inc., Norwalk, CT, USA).

Since all samples were placed in buffer the $\mathrm{OH}$ stretching modes (3400-3200 $\mathrm{cm}^{-1}$ and $\left.1800-1500 \mathrm{~cm}^{-1}\right)$ from water molecules overlap the bands of interest. To eliminate the effect of water on spectra, buffer spectrum at each corresponding temperature was subtracted by using the same software.

Perkin Elmer Spectrum One software was again utilized for spectral analysis. Detailed data analysis was performed on water subtracted sample spectra. The band positions were measured from the center of weight ( $0.75 \times$ peak height positions) and bandwidth value was calculated as the width at $0.75 \times$ height of the signal in terms of $\mathrm{cm}^{-1}$.

\section{DSC Studies and Analysis}

DSC studies and analysis were done in accordance with the literature ${ }^{13,22,24,28}$. For the sample preparation of DSC studies, MLVs containing; pure DPPC, 
1-10-20 mol\% of LCM+DPPC, and 20 mol\%LCM+10 mol \% CHO+DPPC were prepared by the same procedure used in FT-IR studies. Each MLV suspension was first encapsulated in hermetically sealed standard aluminum DSC pans by lid crimper. Then, the sample was analyzed by a Shimadzu DSC-60 Calorimeter (Shimadzu Corporation, Tokyo, Japan). During analysis, each sample was equilibrated at $25^{\circ} \mathrm{C}$ and then heated to $60^{\circ} \mathrm{C}$ at a rate of $0.5^{\circ} \mathrm{C} / \mathrm{min}$. Samples were scanned three times to ensure the reproducibility of the endotherms. Data were analyzed using TA 60 software provided by Shimadzu (Shimadzu Corporation, Tokyo, Japan). Pure DPPC samples resulted in two endothermic thermal events as shown in Figure 2. The temperature at the first peak maximum, named pre-transition, was obtained as $32^{\circ} \mathrm{C}$. The second peak called main phase transition was measured at $41.11^{\circ} \mathrm{C}$. The area under the main transition peak was obtained for the enthalpy $(\Delta H)$ values as performed by Türker-Kaya et al. in their study $(2017)^{13,22}$.

\section{Statistical Analysis}

To evaluate the differences among the samples in comparison with pure DPPC MLVs statistical significance was assessed by post-hoc Tukey HSD following One Way Analysis of Variance (ANOVA) using SPSS Statistics 19.0 program (IBM SPSS Statistics for Windows, Version 19.0. Armonk, NY: IBM Corp). Differences were considered statistically significant when $\mathrm{p}<0.05$.

\section{RESULTS}

Figure 2 shows thermograms of DPPC MLVs with and without LCM and $\mathrm{CHO}$. As demonstrated in the figu- re, in pure DPPC thermogram pre-transition and main transition peaks were obtained as $32^{\circ} \mathrm{C}$ and $41.11^{\circ} \mathrm{C}$, respectively. These values are in accordance with the literature ${ }^{13,23}$. Particularly, the peak maximum of main transition, Tm value, is representative of transition of lipids from gel to liquid phase. In other words, above $41^{\circ} \mathrm{C}$, DPPC lipids are in liquid crystaline phases while below that degree they are in gel phases ${ }^{13,23,26}$.

As shown in Figure 2, both LCMs at all concentrations with $\mathrm{CHO}$ caused disapperance of pre-transition peak. Table 1 illustrates numerical comparisons of $\mathrm{Tm}$ and $\Delta \mathrm{H}$ values of all samples. Table 1 shows a slight decrement in Tm but significant $(p<0.05)$ decrease in $\triangle \mathrm{H}$ values compared to pure DPPC. Indeed, according to Tukey test, there was no statistically difference among Tm of LCM and CHO groups however, $\Delta \mathrm{H}$ values of such groups were found to be different at a significance level of 0.05 . Among all applied concentrations $1 \mathrm{~mol} \%$ of LCM was the most effective one, which caused the highest reduction in $\mathrm{Tm}$ (from $41.11 \pm 0.19$ to $39.60 \pm 1.12$ ) and $\Delta \mathrm{H}$ (from $35.67 \pm 2.70$ to $24.57 \pm 1.08$ ) values, respectively. But with the addition of 10 and $20 \mathrm{~mol} \%$ of LCM these parameters tend to become closer to pure DPPC values. Subse-

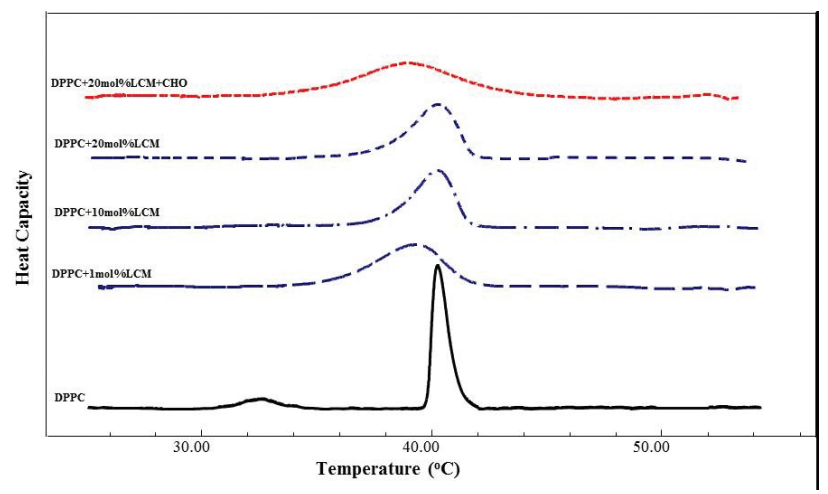

Figure 2. DSC thermograms of DPPC MLVs in the absence and presence of LCM and CHO.

Table 1. Tm and $\triangle H$ values of DPPC MLVs in the absence and presence of LCM and CHO.

\begin{tabular}{|c|c|c|c|c|c|c|}
\hline Sample & $\operatorname{Tm}\left({ }^{\circ} \mathrm{C}\right)$ & $\mathbf{P}$ & $\Delta H(j / g)$ & $\mathbf{P}$ & Bandwidth $(\mathrm{cm}-1)$ & $\mathbf{P}$ \\
\hline DPPC & $41.11 \pm 0.19$ & & $35.67 \pm 2.70$ & & $22.40 \pm 0.85$ & \\
\hline DPPC+1mol\%LCM & $39.60 \pm 1.12$ & 0.49 & $24.57^{*} \pm 1.08$ & 0.001 & $22.19 \pm 1.23$ & 1 \\
\hline DPPC+10mol\% LCM & $40.15 \pm 1.87$ & 0.82 & $25.58 * \pm 2.36$ & 0.002 & $21.94 \pm 1.57$ & 0.98 \\
\hline DPPC+20 mol\%LCM & $40.42 \pm 0.95$ & 0.93 & $26.05 * \pm 1.67$ & 0.003 & $20.58 \pm 0.92$ & 0.30 \\
\hline $\mathrm{DPPC}+20 \mathrm{~mol} \% \mathrm{LCM}+10 \mathrm{~mol} \% \mathrm{CHO}$ & $39.12 \pm 0.65$ & 0.25 & $22.08 * \pm 2.94$ & 0.000 & $20.47 \pm 0.41$ & 0.25 \\
\hline
\end{tabular}


quently, Tm and enthalpy values of DPPC MLVs containing $20 \mathrm{~mol} \%$ of LCM were the closest ones to pure DPPC. This may suggest that LCM effects thermotropic parameters of DPPC lipids independent of its concentration. The presence of $10 \mathrm{~mol} \% \mathrm{CHO}$ was found to behave quite differently, by reducing Tm and also significantly decreasing enthalpy $(p<0.05)$ values mostly in comparison with the other samples.

For FT-IR spectral analysis the wavenumber values of the $\mathrm{CH} 2$ asymmetric $(\sim 2925 \mathrm{~cm}-1)$, the $\mathrm{C}=\mathrm{O}(\sim 1730$ $\left.\mathrm{cm}^{-1}\right)$ and the PO-2 asymmetric $\left(\sim 1225 \mathrm{~cm}^{-1}\right)$ stretching were evaluated, and the bandwidth values of the $\mathrm{CH} 2$ asymmetric stretching were calculated. Figure 3 illustrates FT-IR spectra of pure and $20 \mathrm{~mol} \%$ LCM and CHO containning DPPC MLVs in the wavenumber range of $3000-2800 \mathrm{~cm}^{-1}$ at the liquid crystalline phase. The changes in wavenumber values of the $\mathrm{CH} 2$ asymmetric, the $\mathrm{C}=\mathrm{O}$ and the $\mathrm{PO}-2$ asymmetric bands for pure DPPC, DPPC+20 mol \% LCM and DPPC $+20 \mathrm{~mol} \% \mathrm{LCM}+10 \mathrm{~mol} \% \mathrm{CHO}$ are depicted in Figure $4 A, 4 B$ and $4 C$, respectively. The bandwidth values of the $\mathrm{CH} 2$ asymmetric of the samples are also included in Table 1. As demonstrated in Fig. 3 and Fig. $4 A$, significant $(p<0.05)$ shifting to lower values of the $\mathrm{CH} 2$ asymmetric mode was obtained with addition of LCM at $20 \mathrm{~mol} \%$, and CHO further lowered such impact in both gel and liquid crystalline phases. In comparison with pure DPPC, the bandwidth value of the same mode slightly decreased with the presence of LCM, and $\mathrm{CHO}$ enhanced this reduction (Table 1 ). According to Figures $4 \mathrm{~B}$ and $4 \mathrm{C}, \mathrm{LCM}$ at the highest concentration significantly $(p<0.05)$ lowered the frequency values of $\mathrm{C}=\mathrm{O}$ and $\mathrm{PO}$ - asymmetric stretching modes of DPPC lipids. The presence of $\mathrm{CHO}$ still caused a decrement $(p<0.05)$ in such parameter, however in comparison with LCM sample $\mathrm{CHO}$ showed tendency to increase these wavenumber values. Post-hoc Tukey test revealed that in terms of the $\mathrm{CH} 2$ asymmetric, the $\mathrm{C}=\mathrm{O}$ and the $\mathrm{PO}$-asymmetric wavenumber values $\mathrm{LCM}$ and $\mathrm{CHO}$ groups were significantly different from each other but bandwidth values of these groups did not show any difference.

\section{DISCUSSION}

Considering its low protein binding and level of distribution in body, LCM is expected to incorporate into membrane lipids. In order to provide information for this, in the absence and presence of $\mathrm{CHO}$, the effects of LCM at different concentrations (1-10-20 mol\%) on thermotrophic properties ( $\mathrm{Tm}$ and $\Delta \mathrm{H}$ ), hydration state of head groups, glycerol backbones, lipid dynamics (fluidity) and lipid acyl chain flexibility (ordering) of DPPC MLVs were monitored. Owing to their advantages to study such biophysical features of lipids, DSC and FT-IR spectroscopy were utilized. DSC offers measurement of thermodynamic parameters (i.e. $\Delta \mathrm{H}$ and Tm); FT-IR spectroscopy offers data about lipid dynamics (fluidity), lipid acyl chain flexibility (ordering), hydration state. Thus, these techniques have been extensively utilized in these kinds of works $^{13,17-19,22,24-28}$.

DSC thermogram of pure DPPC displayed pretransition peak around $32^{\circ} \mathrm{C}$, which is related with the mobility of choline and polar head groups of lipids ${ }^{17}$ (Figure 2). The disapperance of pre-transition peak with addition of $\mathrm{CHO}$ and LCMs may suggest extreme broadening and/or disturbance of ripple phase. Since pre-transition peak depends on choline and head groups of lipids, hydration state of such groups directly affects periodic ripples on membrane surface ${ }^{13,24,28}$. Thus, this may indicate that both LCM and CHO accumulate at the surface of bilayer by showing tendency to interact with hydrophilic parts of DPPC lipids. This behavior of $\mathrm{CHO}$ is in accordance with the studies on CHO-DPPC interactions ${ }^{24,25}$. In addition, with regard to LCM data similar result was published related to different antiepileptics ${ }^{12,13}$. Nevertheless, it is worth noting that pre-transition is extremely susceptible to any foreign molecules, perturbation of pre-transition peak may not be associated with alterations in hydration state of lipids ${ }^{12,21}$. In order to bring more clarification to this issue, wavenumber values of $\mathrm{C}=\mathrm{O}$ and $\mathrm{PO}_{2}$-symmetric stretching bands were evaluated within the scope of the present study. The $\mathrm{C}=\mathrm{O}$ mode is attributed to the carbonyl groups of the glycerol backbone near hydrophilic region while $\mathrm{PO}_{2}$-band 
is assigned to head groups of lipids ${ }^{13,17,22,24-27}$. Due to their chemical features both LCM and $\mathrm{CHO}$ are expected to interact with such groups over hydrogen bonding. In detail, LCM has 2 hydrogen bond donors and 3 acceptor counts ${ }^{8}$ while $\mathrm{CHO}$ has 1 hydrogen donating and 1 hydrogen accepting group ${ }^{29}$. Thus, $\mathrm{C}=\mathrm{O}$ and $\mathrm{PO}_{2}$ - would be moiety for LCM and $\mathrm{CHO}$ to form hydrogen bonds. As demonstrated in Figures 4B and $4 C$, significant $(p<0.05)$ decrease in wavenumber values of both peaks in the presence of $20 \mathrm{~mol} \%$ of LCM and $10 \mathrm{~mol} \%$ of $\mathrm{CHO}$, may suggest formation of hydrogen bonds between such groups ${ }^{17,22,28}$. For LCM, the hydrogen bonding can occur between the $\mathrm{C}=\mathrm{O}$ and the $\mathrm{PO}_{2}$ - groups of DPPC lipids and either with $\mathrm{N}-\mathrm{H}$ and $\mathrm{O}$ groups of LCM or water molecules rather than lipids groups of each other. To the best of our knowledge, even though the solubility of LCM is known ${ }^{9}$, such ability of LCM on lipids has not been previously reported. Same result was also obtained in our previous study for gabapentin and levetricetam, both of which have ampiphilic character like $\mathrm{LCM}^{13}$. Even though in the sample containing LCM and $\mathrm{CHO}$ there was still decrement in wavenumber values of $\mathrm{C}=\mathrm{O}$ and the $\mathrm{PO}_{2}$ - modes, the degree of such reduction seemed to be less pronounced than that of LCM itself. This may have resulted from competition between LCM and CHO. Particularly, polar $\mathrm{OH}$ groups of $\mathrm{CHO}$ would make hydrogen bonding with $\mathrm{PCs}$ oxygen atoms in the $\mathrm{C}=\mathrm{O}$ and the $\mathrm{PO}_{2}$ - groups, and water ${ }^{22,24,25}$. In addition, it is also probable that there might be an association between LCM and CHO. But, probability of such influence of $\mathrm{CHO}$ is very low because number of hydrogen bond donor and acceptor groups are 1 and 1 , respectively ${ }^{29}$.

For the evaluation of DSC and FT-IR numerical data we applied post-hoc Tukey test following ANOVA and we were able to compare not only pure DPPC with other samples but also LCM and CHO groups with each other. At the level of significance $(p<0.05)$ there was no difference among each group in $\mathrm{Tm}$ and bandwidth values. However, it should be mentioned that significance level of DPPC+20 mol\% LCM+10 mol\% CHO sample for Tm (0.25) and for bandwidth (0.25) are higher than that of the other samples as shown in Table 1. Even though such finding was expected to be interpreted as no difference among all samples, for model membrane studies such variations may still mean that there is interaction between LCM, CHO and DPPC lipids. This may also reflect as signifcant changes in $\Delta \mathrm{H}$ values as well as the data of FT-IR study.

Figure 2 shows thermograms of all samples, broadening in the main transition curve as well as a reduction in $\mathrm{Tm}$ and $\Delta \mathrm{H}$ values (Table 1 ) with the addition of $\mathrm{LCM}$ and $\mathrm{CHO}$. Since main transition peak is correlated with the mobility of fatty acyl chains ${ }^{17,19}$, such parameters reflect phase behavior of lipids dominated by lipid-lipid and binding of any molecules, which may be further referred to partition of LCM with $\mathrm{CHO}$ into DPPC lipids ${ }^{8,12,14,17}$. As being marker of transition from gel phase to liquid crystaline phases for DPPC lipids, broadened main transition peak may reveal lower number of molecules undergoing transition simultaneously ${ }^{28,30}$. Furthermore, decrement in $\mathrm{Tm}$ and $\mathrm{H}$ may also suggest incorporation of both LCM and $\mathrm{CHO}$, which may mean perturbation of normal phase transition of DPPC lipids ${ }^{30}$. In other words, the total energy involved in the transition is decreased because the number of lipid molecules involved in the temperature-induced transition is reduced ${ }^{24,27,28,30-32}$. This might have resulted from localization of LCM and $\mathrm{CHO}$ in outer hydrophobic cooperative zone of the bilayer, i.e. the region of $\mathrm{C} 1-\mathrm{C} 8$ atoms of the acyl chains by disturbing van der Waals interactions between acyl chains. Moreover, the decrease in Tm may also have resulted from adsorption of water molecules by hydrophilic parts of DPPC lipids. This further reduces the strength of the interactions of adjacent lipid molecules in the bilayer primarily by disruption of polar head group-head group interactions s $^{13,17,32}$ with the presence of LCM as also observed from the frequency values of $\mathrm{C}=\mathrm{O}$ and $\mathrm{PO}_{2}$ - bands. However, it should be stated that the effect of LCM on thermotropic behavior does not depend on its increasing concentration. In detail, the presence of $1 \mathrm{~mol} \%$ of LCM decreases such parameters at a maximum level. This might explain that LCM at low concentration is very effective on thermotropic parameters of DPPC 
lipids. With the addition of $\mathrm{CHO}$, these parameters were lowered at the highest level. This might be caused by higher penetration capacity of $\mathrm{CHO}$ than that of LCM into DPPC bilayers. In particular, it is well-known that in addition to its four ring hydrogen bonding abilities of $\mathrm{OH}$ groups, it could faciliate positioning of $\mathrm{CHO}$ in depth of DPPC membranes. For this reason, even tough $20 \mathrm{~mol} \%$ of LCM tends to behave closer to pure DPPC thermotropic values; presence of $\mathrm{CHO}$ could reverse such action of LCM at high concentrations. This behavior of $\mathrm{CHO}$ can be supported by earlier studies in which only $\mathrm{CHO}$ was added into DPPC systems and, it showed similar effect such as very broaden main transition, and reduction in $\mathrm{Tm}$ and $\Delta \mathrm{H}$ values ${ }^{24,33,34}$.

As obtained from $\mathrm{C}=\mathrm{O}$ and $\mathrm{PO}_{2}$ - modes, hydrogen bonding of LCM and $\mathrm{CHO}$ with both carbonyl and head groups of DPPC lipids may point out that both CHO and LCM have potency to alter lipid acyl chain flexibility and lipid dynamics as reported by Altunayar et al., ${ }^{19}$. To eloborate on this, the effects of these molecules on lipid order and fluidity of DPPC MLVs were also analyzed. The frequency alterations in the $\mathrm{CH}_{2}$ asymmetric stretching band provide information about the order/disorder state (acyl chain flexibility) of membrane lipids ${ }^{13,17,22,24,28,30,32}$. As illustrated in Figure 3 and Figure 4A, LCM at $20 \mathrm{~mol} \%$ led to significant $(p<0.05)$ reduction in wavenumber values in both gel and liquid crystalline phase, which may suggest increased trans conformers within the system indicating a higher order of acyl chain packing and the rigidity of the membrane ${ }^{13,17,32}$. In general, when orderness in lipid bilayer system is observed, higher Tm and enthalpy values are expected ${ }^{31}$. However, the detected decrease in such parameter might be caused by strong hydrogen bonding of LCM with carbonyl and phoshate head groups of lipids. The ordering effect of LCM at high concentration may stand for its stabilizing effect on neuronal membrane to recover and/or to prevent disordered epileptic membrane systems as similarly obtained for levetricetam ${ }^{17}$. Moreover, with the presence of $\mathrm{CHO}$ more decrement observed in Tm value in comparison to LCM sample may suggest that $\mathrm{CHO}$ further stabilizes the membrane

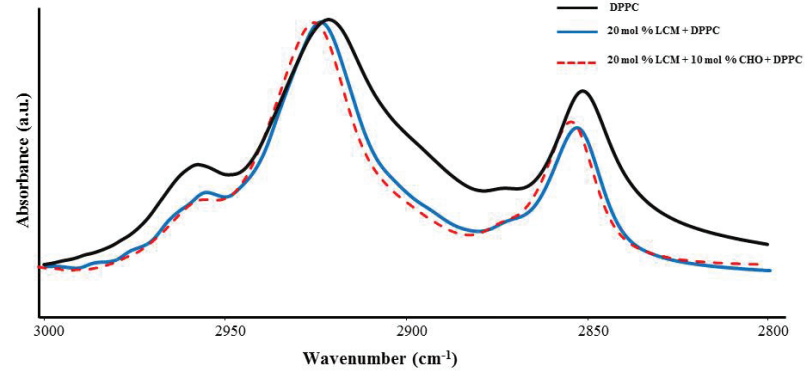

Figure 3. Representative FT-IR spectra of DPPC MLVs in the absence and presence of $20 \mathrm{~mol} \% \mathrm{LCM}$ and $10 \mathrm{~mol} \% \mathrm{CHO}$ in the wavenumber range of $\mathbf{3 0 0 0 - 2 8 0 0 ~ c m - 1}$ at the liquid crystalline phase. The spectra were normalized with respect to the $\mathrm{CH} 2$ asymmetric stretching mode.

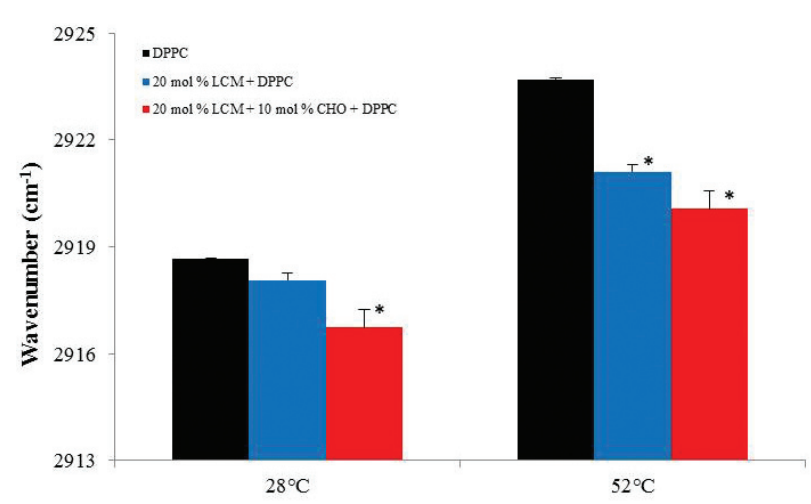

Figure 4A. The wavenumber values of the $\mathrm{CH} 2$ asymmetric stretching mode for DPPC MLVs in the absence and presence of $20 \mathrm{~mol} \% \mathrm{LCM}$ and $10 \mathrm{~mol} \% \mathrm{CHO}$ in gel and liquid crystalline phases.

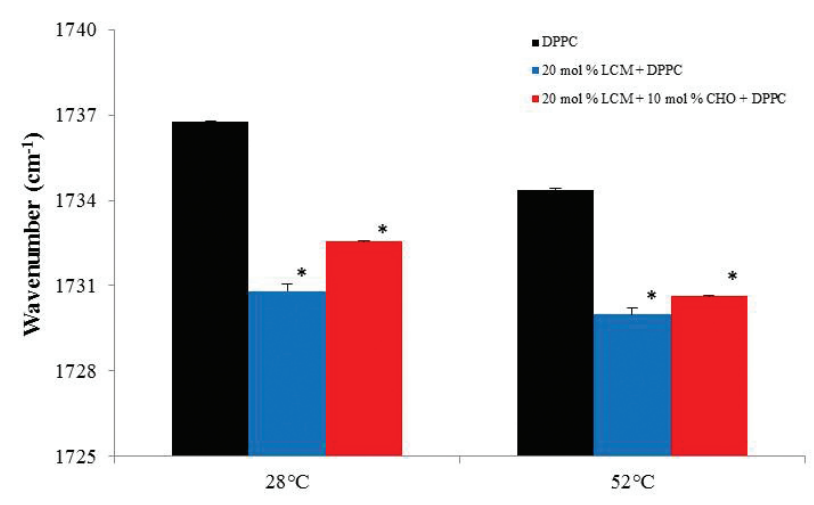

Figure 4B. The wavenumber values of the $\mathrm{C}=\mathrm{O}$ stretching mode for DPPC MLVs in the absence and presence of $20 \mathrm{~mol} \%$ LCM and $10 \mathrm{~mol} \% \mathrm{CHO}$ in gel and liquid crystalline phases.

system, which is also in line with the literature ${ }^{24-27}$.

Knowledge about the dynamics of DPPC MLVs is obtained from the bandwidth of the $\mathrm{CH} 2$ asymmetric stretching vibration $22,28,32$. A slight decrease in the 


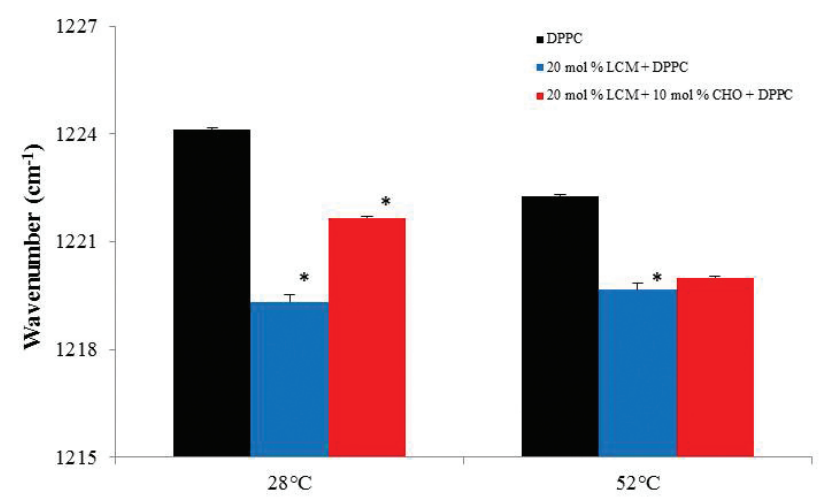

Figure 4C. The wavenumber values of the PO2- asymmetric stretching mode for DPPC MLVs in the absence and presence of $20 \mathrm{~mol} \% \mathrm{LCM}$ and $10 \mathrm{~mol} \% \mathrm{CHO}$ in gel and liquid crystalline phases.

bandwidth of the $\mathrm{CH} 2$ antisymmetric stretching band of DPPC MLVs in the presence of 20 mol\% concentration of LCM suggests the mobility of the hydrocarbon chains showing less fluid system $28,31,32$. The behavior of LCM on fluidity of DPPC MLVs may be related with its preventive effects on generation of action potential. This may be also associated with its use against neuropathic pain ${ }^{35}$. When $\mathrm{CHO}$ was added to the lipid system, lowered bandwith value of $\mathrm{CH} 2$ asymmetric stretching mode may indicate that $\mathrm{CHO}$ makes the system less fluid. In principle, when applied to pure DPPC MLVs, CHO decreases fluidity in gel phase but increases it in liquid crystalline phases ${ }^{24,32}$. However, in our case, the observed decrement in fluidity of DPPC lipids with the addition of $\mathrm{CHO}$ might be resulted from additive reducing impact of LCM on fluidity.

As being the main limitation of the current study, the experiments were conducted on model membrane systems containing two membrane lipids which may mimic biological membrane systems. In order to bring about more clarification on the partition profile of LCM in biological membranes, further studies should be performed on isolated lipids from animal tissues. Furthermore, in this study, the model membrane system MLVs, which is accepted as one of the representative models of biomembranes, and the utilized techniques, FT-IR spectroscopy and DSC, have been widely used to investigate drug-lipid interactions. Even though these techniques and model membrane systems provided general information for binding ability of LCM with membrane lipids, in order to obtain more solid data this study can be extended by using additional model membrane systems such as large unilamellar vesicles and bilayers formed by different lipids. Additionally, other spectroscopic methods giving more specific information like electronspin resonance and nuclear magnetic spectroscopy can be performed.

\section{CONCLUSION}

Our results showed that LCM at applied concentrations (1-10-20 mol\%) can alter thermotrophic parameters of DPPC lipids without depending on increasing concentrations. Investigated concentrations of LCM incorporate into DPPC MLVs and localize within acyl chains of lipids. Additionally, LCM forms strong hydrogen bonding with hydrophilic parts of lipids. Moreover, it also decreases fluidity but increases order. Summarized findings show that binding capability of LCM is highly correlated with its chemical structure. In addition, $\mathrm{CHO}$ further reduced thermotropic parameters, fluidity and hydration state of hydrophilic groups but increased order of DPPC lipids. These results provide ground for better understanding of behavior of LCM within biological membrane systems, especially those containing primarily $\mathrm{PCs}$ and $\mathrm{CHO}$ which are widely found in brain cell membrane.

\section{Acknowledgement}

This study was supported by Scientific Research Foundation of Kocaeli University (BAP-2015/020).

\section{REFERENCES}

1. Mula M. Third generation antiepileptic drug monotherapies in adults with epilepsy. Exp Rev Neurotherap. 2016;16:22-30. https://doi.org/10.1080/14737175.2016.1195264

2. McCleane G. Lacosamide for pain. Expert Opin Inv Drug. 2010;9:66-74.

https://doi.org/10.1517/13543784.2010.511174

3. Biton V. Lacosamide for the treatment of partial-onset seizures. Expert Rev Neurother. 2012;12:506-10. https://doi.org/10.1586/ern.12.50

4. Curia G, Biagini G, Perucca E, Avoli M. Lacosamide: a new approach to target voltage-gated sodium currents in epileptic disorders. CNS Drugs. 2009;23:555-68. https://doi.org/10.2165/00023210-200923070-00002 
5. Niespodziany I, Leclère $N$, Vandenplas $C$, Foerch $P$, Wolff $C$. Comparative study of lacosamide and classical sodium channel blocking antiepileptic drugs on sodium channel slow inactivation. J Neurosci Res. 2013;91:436-43.

https://doi.org/10.1002/jnr.23136

6. Doty P, Hebert D, Mathy FX, Byrnes W, Zackheim J, Simontacchi K. Development of lacosamide for the treatment of partial-onset seizures. Ann NY Acad Sci. 2013;1291:56-68. https://doi.org/10.1111/nyas.12213

7. Hovinga CA. SPM-927 (Schwarz Pharma). I Drugs. 2003;6:479-85.

8. https://pubchem.ncbi.nlm.nih.gov/compound/lacosamide (available on 24.05.2018).

9. May TW, Brandt C, Helmer R, Bien CG, Cawello W. Comparison of lacosamide concentrations in cerebrospinal fluid and serum in patients with epilepsy. Epilepsia. 2015;56:1134-40. https://doi.org/10.1111/epi.13022

10. Beyreuther BK, Freitag J, Heers C, Krebsfanger N, Scharfenecker U, Stöhr. Lacosamide: a review of preclinical properties. CNS Drug Rev. 2007;13:21-42. https://doi.org/10.1111/j.1527-3458.2007.00001.x

11. Cawello W, Boekens H, Bonn R. Absorption, disposition, metabolic fate and elimination of the anti-epileptic drug lacosamide in humans: mass balance following intravenous and oral administration. Eur J Drug Metab Pharmacokinet. 2012;37:241-8. https://doi.org/10.1007/s13318-012-0093-x

12. Suwalskya M, Mennickent S, Norris B, Villenac F, Cuevas F, Sotomayord CP. The antiepileptic drug diphenylhydantoin affects the structure of the human erythrocyte membrane. $Z$ Naturforsch. 2004;59:427-31. https://doi.org/10.1515/znc-2004-5-625

13. Türker-Kaya S, Kına A, Alın S. Divergent interaction profiles of gabapentin and levetiracetam with dipalmitoylphosphatidylcholine lipids. Int J Epilepsy. 2017;4:150-8. https://doi.org/10.1016/j.ijep.2017.09.001

14. Peetla C, Stine A, Labhasetwar V. Biophysical interactions with model lipid membranes: applications in drug discovery and drug delivery. Mol Pharmaceutics. 2009;6:1264-76. https://doi.org/10.1021/mp9000662

15. Shrestha $H$, Bala R, Arora S. Lipid-based drug delivery systems. J Pharmaceutics. 2014;801820:1-10. https://doi.org/10.1155/2014/801820

16. Chu-Shore CJ, Thiele EA. New drugs for pediatric epilepsy. Semin Pediatr Neurol. 2010;17:214-23. https://doi.org/10.1016/j.spen.2010.10.003

17. Turker S, Wassall S, Stillwell W, Severcan F. Convulsant agent pentylenetetrazol does not alter the structural and dynamical properties of dipalmitoylphosphatidylcholine model membranes. J Pharma Biomed Anal. 2011;54:379-86. https://doi.org/10.1016/j.jpba.2010.09.002

18. Liossi A, Ntountaniootis D, Becker-Baldus J. Exploring the interactions of irbesartan and irbesartan-2-hydroxylpropylbeta-cyclodextrin complex with model membranes. BBABiomemb. 2017;1862:1089-98.

https://doi.org/10.1016/j.bbamem.2017.03.003

19. Barroso R, Basso G, Costa-Filho A. Interactions of the antimalarial amodiaquine with lipid model membranes. Chem Phys Lipid. 2015;186:68-78. https://doi.org/10.1016/j.chemphyslip.2014.12.003

20. Alberts B, Johnson A, Lewis J, Raff M, Roberts K, Walter P. The Lipid Bilayer. Alberts B, Johnson A, Lewis J, Raff M, Roberts $\mathrm{K}$, Walter P, editors. Molecular Biology of the Cell. New York: Garland Science; 2002. p.1120-1305.

21. Wang Y, Gkekab P, Fuchs JE, Liedl KL, Cournia Z. Biomemb- ranes DPPC-cholesterol phase diagram using coarsegrained molecular dynamics simulations. BBA-Biomemb. 2016;1858:2846-57. https://doi.org/10.1016/j.bbamem.2016.08.005

22. Sahin I, Bilge D, Kazanci N, Severcan F. Concentration dependent effect of melatonin on DSPC membrane. J Mol Struc. 2013;1052:183-8.

https://doi.org/10.1016/j.molstruc.2013.08.060

23. Stillwell W. Lipid Membrane properties. Stillwell W, editor. An Introduction to Biological Membranes. London: Elsevier; 2016. p.181-220.

24. Altunayar C, Sahin I, Kazancı N. A comparative study of the effects of cholesterol and desmosterol on zwitterionic DPPC model membranes. Chem Phys Lipids. 2015;188:37-45. https://doi.org/10.1016/j.chemphyslip.2015.03.006

25. Benesch MGK, Mannock DA, Lewis H, McElhaney RN. A calorimetric and spectroscopic comparison of the effects of lathosterol and cholesterol on the thermotropic phase behavior and organization of dipalmitoylphosphatidylcholine bilayer membranes. Biochem. 2011;50:9982-97. https://doi.org/10.1021/bi200721j

26. Alves I, Stanev G, Gilmar CT. The interaction of antipsychotic drugs with lipids and subsequent lipid reorganization investigated using biophysical methods. BBA-Biomemb. 2011;1808:2009-18. https://doi.org/10.1016/j.bbamem.2011.02.021

27. Hendrich AB, Michalak K, Wesolowska O. Phase separation is induced by phenothiazine derivatives in phospholipid/sphingomyelin/cholesterol mixtures containing low levels of cholesterol and sphingomyelin. Biophys Chem. 2007;130:32-40. https://doi.org/10.1016/j.bpc.2007.07.001

28. Ezer N, Sahin I, Kazanci N. Alliin interacts with DMPC model membranes to modify the membrane dynamics: FTIR and DSC Studies. Vib Spect. 2017;89:1-8. https://doi.org/10.1016/j.vibspec.2016.12.006

29. https://pubchem.ncbi.nlm.nih.gov/compound/cholesterol (available on 24.05.2018).

30. Wiedmann TS, Trouard T, Shekar S, Polikandritou M, Rahman YE. Interaction of cyclosporine A with dipalmitoylphosphatidylcholine. BBA. 1990;1023:12-8. https://doi.org/10.1016/0005-2736(90)90003-7,0.68.

31. Mendelsohn R. IR spectroscopy of lipid chains theoretical background and applications to phase transitions, membranes, cells and tissues. Yeagle P. (editor). The Structure of Biological Membranes. New York: Taylor\&Francis Group; 2012. p.91-116.

32. López-García F, Micol V, Villalaín J, Gómez-Fernández GC. Infrared spectroscopic studies of the interaction of diacylglycerols with phosphatidylserine in the presence of calcium. BBA. 1993;1169:264-72. https://doi.org/10.1016/0005-2760(93)90250-D

33. Ricci $M$, Oliva $R$, Del Vecchio R, Paolantoni $M$, Sassi P. DMSO-induced perturbation of thermotropic properties of cholesterol-containing DPPC liposomes. BBA-Biomemb. 1858;2016:3024-31. https://doi.org/10.1016/j.bbamem.2016.09.012

34. Yonar D, Sunnetcioglu M. Effect of cis-(Z)-flupentixol on DPPC membranes in the presence and absence of cholesterol. Chem. Phys. Lipid. 2016;198:61-71. doi:10.1016/j.chemphslp.2016.06.002

35. Beyreuther B, Callizot N, Stohr T. Antinociceptive efficacy of lacosamide in a rat model for painful diabetic neuropathy. Eur J Pharmacol. 2006;539:64-70. https://doi.org/10.1016/j.ejphar.2006.04.009 